\title{
USE OF VIRUSES FOR PEST CONTROL IN BRAZIL: THE CASE OF THE NUCLEAR POLYHEDROSIS VIRUS OF THE SOYBEAN CATERPILLAR, ANTICARSIA GEMMATALIS
}

\author{
FLÁVIO MOSCARDI
}

EMBR APA - Soybean National Research Center, Caixa Postal 1061, 86001 Londrina, PR, Brasil

Among the different families or groups of insect viruses (Tinsley \& Kelly, 1985), those belonging to the Baculoviridae, especially the nuclear polyhedrosis (NPV) and granulosis (GV), have been most studied and developed as microbial insecticides. All NPV and GV studied so far, regarding their safety to vertebrates, plants, and non target invertebrates, have provided considerable amount of evidence that these agents can be considered safe to these organisms (Burges et al., 1980; Groner, 1986). The most studied virus is probably the NPV of Heliothis spp., the first viral insecticide registered in U.S.A., in 1975 (Ignoffo \& Couch, 1981), paving the way for registration of other viruses in that country, such as the NPVs of Orgyia pseudotsugata, Lymantria dispar, and Neodiprion sertifer, all pests of forests (Huber, 1986). Other baculoviruses have been developed as commercial or experimental formulations in different regions of the world, including, among others, the NPV of Autographa californica (U.S.A.), the NPV of Mamestra brassicae (Europe), the NPVs of Heliothis armigera and Spodoptera litura (China), and the GV of Cydia pomonella (U.S.A., Europe, U.R.S.S.).

In Brazil, developments towards use of viruses for pest control are more recent, but with significant results. Three viruses are currently in use: The NPV of Anticarsia gemmatalis (Lep. Noctuidae), the first virus used in Brazil, being applied in extensive areas of soybean; the GV of Erynnyis ello (Lep., Sphingidae), applied over 2.000 ha of cassava in the country; and the GV of Diatraea saccharalis (sugarcane borer) (Lep., Pyralidae), currently applied in small scale as an experimental product in sugarcane.

The objectives of this paper will be to present an overview on research developments and current status of the program for use of the NPV of $A$. gemmatalis (AgNPV) in Brazil, as well as discuss its recent achievements and future perspectives.

\section{RESEARCH DEVELOPMENTS}

An NPV of $\boldsymbol{A}$. gemmatalis was first reported in 1962 from dead larvae collected in alfafa fields in Peru (Steinhaus \& Marsh, 1962). In Brazil, an AgNPV was isolated as early as 1972, in the region of Campinas, state of Sao Paulo, being described as a multiple embbeded NPV (Allen \& Knell, 1977), followed by isolations in other regions (Carner \& Turnipseed, 1977; Gatti et al., 1977; Moscardi, unpublished). Initial field tests conducted in Florida (Moscardi, 1977; Moscardi et al., 1981) and in South Carolina (Carner \& Turnipseed, 1977), indicated the AgNPV as a potential biological insecticide to be used in soybean integrated pest management programs.

In Brazil, $A$. gemmatalis is the major desfoliator over ca. 11.0 million hectares planted with soybean, being responsible for the highest volume of insecticides anually applied on this crop. Beggining in 1979, the Soybean National Research Center of EMBRAPA (CNPSo-EMBRAPA) concentrated strong research effort towards developing an AgNPV as a safe, nonpolluting, and selective biological insecticide for use against the insect in lieu to chemical pesticides. Research with an AgNPV isolate, obtained in Londrina, state of Parana, in 1979, provided the basis for defining parameters for efficient use of the virus at the farmer level as well as gradually improving the program. Most important research findings were presented or reviewed by Moscardi \& Corso (1981), Moscardi $(1983 ; 1986 ; 1987)$ and Moscardi \& CorreaFerreira (1985), and can be summarized as follow:

Specificity - The AgNPV showed high specificity to $A$. gemmatalis, being able to infect, in laboratory bioassays, other lepidop- 
terous species such as Bombyx mori (silkworm), Chlosyne lacinia saundersii (sunflower caterpillar), Spodoptera latifascia (pod worm), and Trichoplusia ni (cabbage looper), only at very high doses, while the natural host (A. gemmatalis) presented high susceptibility to the virus $(120$ - to 250,000 - fold differences compared to the other species). The silkworm was the least susceptible, with 2.0 to $3.7 \%$ mortality at 2.5 to $3.0 \times 10^{6}$ polyhedron inclusion bodies (PIB)/larva, indicating that the AgNPV would not represent a risk for the silk industry, even if used extensively on soybean crops near silkworm rearing facilities. Other studies, conducted in U.S.A., also indicated low susceptibility of non-host species, such as Pseudoplusia includens, Heliothis spp., and Spodoptera spp. (Carner et al., 1979).

Field dosages and effect on leaf consumption - Trials conducted in Brazil, during the $1979 / 80$ season, with virus dosages varing from 10 to 320 larval equivalents (LE)/ha (1 LE $\cong$ 1.5 to $2.0 \times 10^{9} \mathrm{PIB}$ ), showed that substantial mortality (ca. 70\%) was obtained even at the lowest dose. At $40 \mathrm{LE} /$ ha, mortality was over $80 \%$ and approached $100 \%$ at the highest doses, if applications were directed against small larvae $(<1.5 \mathrm{~cm})$. This field performance of the AgNPV was further confirmed on different trials at $50 \mathrm{LE} / \mathrm{ha}$. In field trials, larval mortality usually began at the 6th day and peaked on day 7 or 8 after aplication; however, larvae practically ceased feeding at the 4th day post treatment. Laboratory experiments with third instar larvae confirmed these observations, with diseased larvae consuming an average of only $27 \mathrm{~cm}^{2}$, compared to $108 \mathrm{~cm}^{2}$ of leaf surface by healthy larvae. More recent data (Zonta, 1987) show a higher reduction in leaf feeding for earlier larval instars at high doses.

Effect of host age and density on virus efficacy - Anticarsia gemmatalis showed a marked reduction in susceptibility to the AgNPV as the insect progressed in larval development (40 to 50 fold from first to fifth instar). A very sud. den decrease occurred after the fourth instar, indicating that field application of AgNPV should be directed against small larvae $(<1.5 \mathrm{~cm})$. Since diseased larvae continue feeding for some days, timing applications based on larval density is of paramount importance for efficaceous use of the AgNPV. Artificial infestation of field-caged soybean plants by different larval densities, allowed determination of maximum insect level at 20 small larvae $/ \mathrm{m}$ of row, for AgNPV use at farmer level.

Persistence on leaves and in the soil - AgNPV persistence of activity on leaves was shown to be relatively short, varying with the type of preparation. Half life of purified virus was less than 4 days, whereas that of a crude and a purified preparation with a clay-adjuvant was ca. 6 and 7 days, respectively, for a virus dose of ca. $1.0 \times 10^{11} \mathrm{PIB} / \mathrm{ha}$. Despite this low persistence, one AgNPV application usually maintained $A$. gemmatalis below damaging levels throughout the season, in different field trials, due to an increase in virus load on the crop, resulted from high quantities liberated from dead larvae. Persistence in heavy-clay soil was studied for a two-year period, in no-till and conventional tillage systems. Fourteen months after virus deposition in the soil AgNPV retained ca. $40 \%$ of original activity in the no-till system compared to ca. $13 \%$ in the tillage system (Moscardi, unpublished). After 24 months, viral activity was ca. $26 \%$ and $8 \%$ in both areas, respectively. The remaining active virus was sufficient to contribute with substantial mortality of naturally occurring $\boldsymbol{A}$. gemmatalis larvae in both areas, in the two subsequent seasons after virus deposition in the soil.

Interaction with other biocontrol agents Possible effects of AgNPV application on development of Nomuraea rileyi epizootics were investigated under laboratory and field conditions, since this fungus has an important role in natural regulation of $A$. gemmatalis larval populations on soybean. Simultaneous larval infection by both pathogens, at different doses, showed an apparent antagonism between them, when compared to expected additive mortalities, and a clear predominance of AgNPV over the fungus in effectiveness. However, when the virus was offered to larvae $24 \mathrm{~h}$ after inoculation with $N$. rileyi, the latter tended to cause mortalities comparable to when it alone was applied, resulting in a consequent reduction in virus contribution to total mortality. Similar results were obtained with application of the two pathogens in field plots, indicating that use of AgNPV over a large area may lead to epizootic delay and reduction of $N$. rileyi inoculum in situations where the virus is applied before or at the beginning of a $N$. rileyi epizootic on $A$. gemmatalis. 
Studies conducted with insect predators have shown the importance of these agents in AgNPV dissemination. Laboratory tests showed that the virus retained most of its activity after passage through the digestive tract of the carabids Calosoma granulatum, Callida spp. and Lebia concinna, the coccinelid Eriopis connexa and the hemipterous Nabis sp. and Podisus sp. Release of predators previously fed or sprayed with AgNPV, in screen cages containing healthy larvae on soybean plants, resulted in substantial larvae mortality by AgNPV. Furthermore, extracts of predators, collected in virus-treated fields, showed high activity on laboratoryreared larvae, with peak activity accurring at the time of greatest larval mortality by AgNPV in the field (Polato et al., unpublished). These results may help explain sudden increases in virus-killed $A$. gemmatalis larvae in untreated areas that are near AgNPV-treated fields, as has been observed in many instances in Brazil.

Interaction with pesticides - A study involving mixtures of AgNPV with eight insecticides and two postemergence herbicides showed that virus activity was not affected by none of the tested pesticides. On the other hand, mixtures of AgNPV with low rates of insecticides $(1 / 4$ to $1 / 8$ of the recommended doses), applied against $A$. gemmatalis populations which had surpassed the threshold for virus use, were efficient in reducing high populations of the insect and in avoiding economic damage to the crop. This type of tactic is being further evaluated and may prove usefull for situations where the AgNPV could not be used by itself, based on current recommendations for virus application.

AgNPV formulation - Studies towards development of a simple, standardized formulation of the AgNPV have been conducted since 1984 at the CNPSo-EMBRAPA, in order to improve storage, transportation and use of the pathogen (Moscardi, unpublished). Initial studies with a wettable powder obtained through precipitation with lactose and acetone indicated that the virus lost significant activity in the process. Further studies with another formulation, obtained through air drying and milling of a caolin-based AgNPV slurry, showed it to be adequate for use at the farmer level in different field trials. This formulation has shown persistence of activity of at least 4 months in ambient conditions, of more than a year at $4-6{ }^{\circ} \mathrm{C}$, and of much longer periods when frozen (Moscardi, unpublished).
PRODUCTION AND USE OF AgNPV IN BRAZIL

A pilot program for AgNPV use was conducted during the 1980/81 and 1981/82 soybean seasons by CNPSo-EMBRAPA, with collaboration of official extension service and farmer cooperatives in the state of Parana. The program consisted of using contiguous fields (virus treated, insecticide treated, and a check) of at least one ha each, in soybean farms in different regions of the state. Virus was applied at $1,0 \times 10^{11} \mathrm{PIB} / \mathrm{ha}$ as a crude preparation when the majority of larvae were still small and had not surpassed $20 / \mathrm{m}$ of row, whereas insecticides were applied according to current soybean integrated pest management (IPM) recommendations. In the remainder of each soybean farm, the farmer himself would apply insecticide according to his own practice. In all regions the AgNPV was efficient in mantaining $A$. gemmatalis populations and defoliation below economic thresholds. In all locations seed yield did not differ between AgNPV and insecticide plots, while untreated plots usually yielded much less. On the other hand, in virustreated areas the pathogen was applied only once, whereas insecticide-treated areas received a higher number of applications, resulting in a cost up to $70 \%$ lower in virus-treated areas. Results of the pilot program clearly showed the importance and advantages of AgNPV use against $A$. gemmatalis, in relation to chemical insecticide use in soybean IPM, such that in the $1982 / 83$ season, CNPSo-EMBRAPA, official extension and farmer cooperatives started to implement AgNPV use, initially in the states of Parana and Rio Grande do Sul, and, afterwards, in other soybean-producing states.

Initially, the program consisted of expanding an existing $A$. gemmatalis colony at CNPSoEMBRAPA for virus production, with the objective of providing extension service personnel and farmer cooperatives with an initial supply for further multiplication of the pathogen on naturally occurring $A$. gemmatalis populations. Virus production in the laboratory was much improved later through adaptations of existing rearing procedures (Hoffmann-Campo et al., 1985), as well as through development of an improved methodology for virus production, taking into account virus dose, age of larvae at inoculation and number of larvae per rearing container (Moscardi et al., 1985), as shown in the figure. 


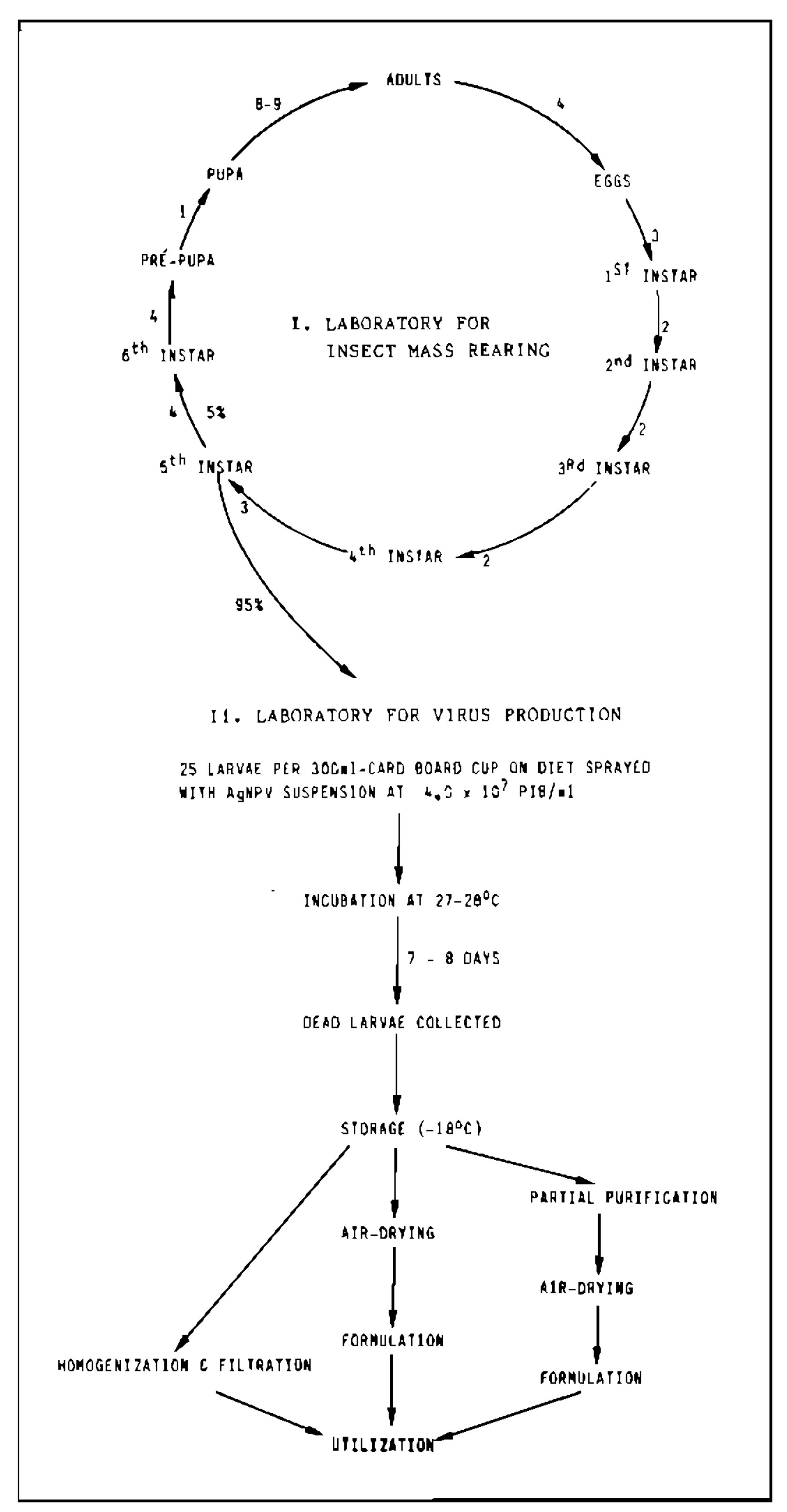

Procedures for mass production of the nuclear polyhedrosis virus of Anticarsia gemmatalis (AgNPV) under laboratory conditions at EMBRAPA-CNPSo, and the different ways AgNPV-dead larvae are processed for pathogen utilization in Brazil. Numbers between each $A$. gemmatalis developmental phase indicate number of days spent in each phase.

Other methods of AgNPV production were developed, so as to allow large yields of the pathogen at lower costs and complement laboratory production. One of these consists of mass release of laboratory-reared larvae on soybean treated with AgNPV, in $2.0 \times 2.0$ field screen cages. Other method consists of releasing laboratory-reared adults in large screened houses ( 24 to $160 \mathrm{~m}^{2}$ ) in soybean fields, with the resulting larval populations being treated with the AgNPV. In both cases, AgNPV dead larvae are collected from the 7th to 10th day post application and frozen for further use or processing (Moscardi \& Oliveira, 1984). The less costly method, however, has been the AgNPV production on naturally occurring A. gemmatalis populations during the soybean season. In the last three seasons, this method has allowed EMBRAPA-CNPSo to produce an average of $30-40 \mathrm{~kg}$ of AgNPV-dead larvae/ day, considering 30-40 collectors/day (Moscardi, unpublished). In the $1987 / 88$ season, total production during 30 days reached $1,500 \mathrm{~kg}$, enough for treatment of $75,000 \mathrm{ha}$.

Up to $1985, \mathrm{AgNPV}$ was used at farmer level only as crude preparations (Moscardi \& CorreaFerreira, 1985). However, development at CNPSO-EMBRAPA of a caolin-based wettable powder formulation allowed use of a standardized AgNPV preparation since the 1986/87 season. Since then, all virus produced at CNPSoEMBRAPA started being processed into this formulation before release to farmers. Despite its availabity, farmers are also instructed by extension personnel to collect AgNPV-dead larvae in treated areas, so as to apply the pathogen in larger areas or store the larvae frozen for use in the subsequent season. A simple monitoring program was devised for testing the quality of the material being multiplied and collected under field conditions, and is being employed in different laboratories in south of Brazil, so as to avoid use of unproperly collected or preserved material.

\section{PROGRESS IN AgNPV USE}

AgNPV effective use in Brazil started in the $1982 / 83$ soybean season, when ca. 2,000 ha were treated with the pathogen, with a progressive increase in subsequent years (Table). A substantial increase in AgNPV-treated area occurred in the 1984/85 season (ca. 200,000 ha), after the implementation of regional production units, established in existing laboratories of research institutions, universities and farmer cooperatives in Parana and Rio Grande do Sul, the largest soybean-producing states in the country. These units increased availability of AgNPV and farmer interest on the technology on a regional basis. AgNPV-treated area kept increasing afterwards, reaching over 500,000 ha in the $1987 / 88$ season.

The rapid expansion in virus - treated area in Brazil can be attributed to the simple strategies adopted, including the possibility of using 
field - collected AgNPV by farmers. The association of laboratory production with other methods, especially in the field, by EMBRAPACNPSo and other institutions, taking advantage of high natural occurrence of $\boldsymbol{A}$. gemmatalis and low cost of labor in the country, has allowed application of the final formulated product at a cost of US $\$ 2.00 /$ ha compared to US $\$ 5.00 /$ ha for chemical insecticides.

\section{TABLE}

Estimated area treated with AgNPV in Brazil, in different soybean seasons ${ }^{\mathrm{a}}$

\begin{tabular}{cc}
\hline Season & Treated area (hectares) \\
\hline $1982 / 83$ & 2,000 \\
$1983 / 84$ & $15,000-20,000$ \\
$1984 / 85$ & 200,000 \\
$1985 / 86$ & 300,000 \\
$1986 / 87$ & 350,000 \\
$1987 / 88$ & 500,000 \\
\hline
\end{tabular}

a Based on regional information.

The procedures developed in Brazil for AgNPV production and use have been adopted by other South American Countries, such as Argentina and Paraguay, where the pathogen has been employed in ca. 2,000 and 18,000 ha, respectively, in a single season, with perspectives of rapid increase in AgNPV usage.

\section{FUTURES PERSPECTIVES FOR AgNPV USE}

Considering present rates of increase in AgNPV use, it is expected that treated area may reach 2.0 million ha in three years, which would represent ca. $20 \%$ of the soybean cultivated area in Brazil. Since the $1987 / 88$ season, AgNPV production at CNPSo-EMBRAPA and other institutions has not been sufficient to attend increasing farmer's demand for the pathogen. Therefore, it is recognized that existing programs for AgNPV production have to be expanded, and others have to be created, including the participation of private industries interested in developing commercial products based on AgNPV. In fact, currently production and formulation technologies are being transferred by CNPSo-EMBRAPA to six private industries, which are in the process of registering the AgNPV for use in Brazil. At least two of these industries are expected to have their AgNPV products in the market for the 1989/90 soybean season. Despite the expected increase in the availability of formulated AgNPV, farmer's multiplication of the virus on naturally occurring $\boldsymbol{A}$. gemmatalis and use of crude preparations will continue to play an important role for the expansion of AgNPV use in Brazil, especially in the south, among farmers already familiarized with the procedure.

Presently, a research project (EMBRAPA/ University of Florida) is concentrating efforts on the study of genetic stability of the virus, aiming at detecting genomic variations and their relation to virulence of AgNPV sequentially passed through $A$. gemmatalis in annual largescale applications in the field. Studies are also directed to the possibility of in vitro selection of more virulent AgNPV variants from wild type geographical isolates. These information, associated to those related to the refinement of mass production procedures and formulations, are expected to bring about considerable improvement in AgNPV use as a microbial insecticide in Brazil.

\section{REFERENCES}

ALLEN, G. E. \& KNELL, J. D., 1977. A nuclear polyhedrosis virus of Anticarsia gemmatalis: I. Ultrastructure, replication, and pathogenicity. Florida Entomologist, 60: 233-240.

BURGES, H. D.; CROIZIER, G. \& HUBER, J., 1980. A review of safety tests on baculoviruses. Entomophaga, 25: 329-339.

CARNER, G. R.; HUDSON, J. S. \& BARNET, O. W., 1979. The infectivity of a nuclear polyhedrosis virus of the velvetbean caterpillar for eight Noctuidae hosts. J. Invertebr. Pathol., 33: 211-216.

CARNER, G. R. \& TURNIPSEED, S. G., 1977. Potential of a nuclear polyhedrosis virus for control of the velvetbean caterpillar in soybean. $J$. Econ. Entomol, 70:608-610.

GATTI, I. M.; SILVA, D. M. \& CORSO, I. C., 1977. Polyhedrosis occurrence in caterpillars of Anticarsia gemmatalis Hübner, 1818 in South of Brazil. IRCS Medical Sci.: Cell Membr. Biol.; Environ. Biol. an Medicine; Exper. Animal Microbiol., Parasitology and Infectious Diseases, Lancaster, 5: 136.

GRONER, A., 1986. Specificity and safety of baculoviruses, vol. I, p. 177-202. In R. R. Granados \& B. A. Federici, The biology of baculovinuses: biological properties and molecular biology. CRC Press, Boca Raton, U.S.A.

HOFFMANN-CAMPO, C. B.; de OLIVEIRA, E. B. \& MOSCARDI, F., 1985. Criação massal da lagarta da soja (Anticarsia gemmatalis). EMBRAPACNPSo. Documentos 10, Londrina, Brasil, 23 p.

HUBER, J., 1986. Use of baculovinus in pest management programs, vol. II, p. 181-202. In R. R. Granados \& B. A. Federici, The biology of baculoviruses: practical application for insect control. CRC Press, Boca Raton, U.S.A.

IGNOFFO, C. M. \& COUCH, T. L., 1981. The nucleo- 
polyhedrosis virus of Heliothis species as a microbial insecticide, p. 329-362. In H. D. Burges, Microbial control of pests and plant diseases. Academic Press, London.

MOSCARDI, F., 1977. Control of Anticarsia gemmatalis Hübner on soybean with a baculovirus and selected insecticides and their effect on natural epizootics of the entomogenous fungus Nomuraea rileyi (Farlow) Samson. Msc. Thesis University of Florida, Gainesville.

MOSCARDI, F., 1983. Utilizaçāo de Baculovirus anti. carsia para o controle da lagarta da soja, Anticarsia gemmatalis. EMBRAPA-CNPSo, Com. Tec. 23, Londrina, Brasil, $21 \mathrm{p}$.

MOSCARDI, F., 1986. Utilização de vírus para o controle da lagarta da soja, p. 188-202. In S. B. Alves, Controle Microbiano de Insetos. Editora Manole, São Paulo.

MOSCARDI, F., 1987. Uso de vírus no controle de pragas, p. 191-262. In Anais do Encontro Sul.Brasileiro de controle biológico de pragas, 1. Associação dos Engenheiros Agrônomos, ed., Passo Fundo, Brasil.

MOSCARDI, F.; ALLEN, G. E. \& GREENE, G. L., 1981. Control of the velvetbean caterpillar by nuclear polyhedrosis virus and insecticides and impact of treatments on natural incidence of the entomopathogenic fungus Nomuraea rileyi. $J$. Econ. Entomol, 74: 480-485.

MOSCARDI, F. \& CORREA-FERREIRA, B. S., 1985. Biological control of soybean caterpillars, p. 703711. In R. Shibles, World Soybean Research
Conference III: Proceedings. Westview Press, London.

MOSCARDI, F. \& CORSO, I. C., 1981. Açâo de Baculovirus anticarsia sobre a lagarta da soja (Anticarsia gemmatalis, Hübner, 1818) e outros lepidópteros, p. 5 1-57. In Anais do Seminário Nacional de pesquisa de Soja, 2. EMBRAPA-CNPSo, Londrina, Brasil.

MOSCARDI, F.; LEITE, L. G. \& ZAMATARO, C. E. O., 1985. Produção massal de Baculovirus anticarsia em laboratório, p. 134-144. In Resultados de Pesquisa de Soja 1984/85. EMBRAPACNPSo, Documentos 15, Londrina, Brasil.

MOSCARDI, F. \& OLIVEIRA, R. F., 1984. Estudo da viabilidade de produção em massa de Baculovirus anticarsia em telados de campo, p. 206-208. In Resultados de Pesquisa de Soja 1983/84. EMBRAPA-CNPSo, Londrina, Brasil.

STEINHAUS, E. A. \& MARSH, G. A., 1962. Report of diagnosis of diseased insects, 1951-1961. Hilgardia, 33: 349-390.

TINSLEY, T. W. \& KELLY, D. C., 1985. Taxonomy and nomenclature of insect pathogenic viruses, p. 3-25. In K. Maramorosch \& K. E. Shermann, Viral Insecticides for biological control. Academic Press, New York.

ZONTA, R. C. C., 1987. Consumo e utilizaçāo do alimento por Anticarsia gemmatalis Hübner, 1818 (Lepidoptera, Noctuidae), infectada com virus de poliedrose nuclear (VPN) e Nomuraea rileyi (farlow) Samson. MSc. Thesis. Universidade Federal do Paraná, Curitiba, Brasil. 